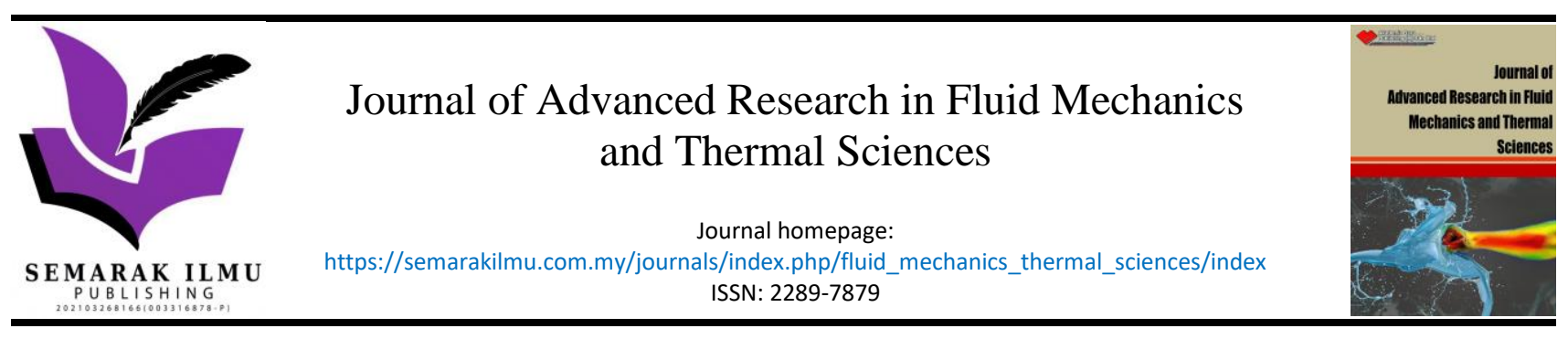

\title{
Feasibility Study of Bio-fuel As a Sustainable Product of Biomass: An Overview of Its Fundamentals, Application and Environmental Impact
}

\author{
Abdelgader A. S. Gheidan ${ }^{1, *}$, Mazlan Abdul Wahid ${ }^{1}$, Fudhail Abdul Munir ${ }^{2}$, Anthony Chukwunonso \\ Opia $^{1}$
}

High-Speed Reacting Flow Laboratory, School of Mechanical Engineering, Universiti Teknologi Malaysia, 81310 UTM Skudai, Johor, Malaysia

Faculty of Mechanical Engineering, Universiti Teknikal Malaysia Melaka, 76100 Hang Tuah Jaya, Melaka, Malaysia

\section{ARTICLE INFO}

\section{Article history:}

Received 4 June 2021

Received in revised form 2 September 2021

Accepted 5 September 2021

Available online 29 October 2021

\section{Keywords:}

Biomass; Bio-fuel; Sustainability; Biofuel conversion; Emission control

\section{ABSTRACT}

\begin{abstract}
The energy crisis and ecological disasters have become a critical problem in recent decades. The human activities through industrial operations increase emissions and other pollutant particulates in the world as a result of steady patronage on fossil feedstock. Several experiments were performed to identify an alternative fuel meeting the rising energy demand. Biomass (bio-fuel) has recently been developed as an economical fuel, environmentally friendly resource, renewable and sustainable fuel. Approximately 350 crop plants were evaluated and some of them could be considered as suitable alternative diesel engine fuels. To increase the bio-fuel quantity globally, apart from crops, other biomaterial sources are considered potential in biofuel production. It was shown that the properties of biofuel combustion are identical to fossil. In the experimental combustion of biodiesel blends, higher ignition pressure and temperature, shorter ignition delay, and higher peak release were recorded. This paper is a literature review on the need for biofuels as a global renewable fuel resource and aims to explain the characteristics of combustion and pollutant formation in the application of biofuels. The study also stated the resources, the use of biogas and its emission impact in flameless combustion mode. With holistic adoption of biomass source of fuel together with the modern conversion techniques, issues from fuel emissions will be mitigated.
\end{abstract}

\section{Introduction}

Coal and petroleum otherwise known as fossil fuel has predominantly used for power generation globally. Since development cannot be achieved without industrial/ technological contributions. The use of those fossil fuels in the actualization of economic growth and transformation through industries affects mankind via pollution. Because of these confronted challenges, the academic decline of fossil fuels and environmental concerns have persuaded study on new fuel supplies and the disposal of unsustainable energy resources worldwide [1-6]. Although many combustion techniques have been introduced in solving the pollution problems, yet not sufficient since some emissions are still recorded. The chemical conversion of fuels (fossil and biofuel) to generate heat

\footnotetext{
* Correponding author.

E-mail address: gheidan015@gmail.com
}

https://doi.org/10.37934/arfmts.88.2.106122 
and power, follows various combustion step, also results in dangerous emissions instead of useful $\mathrm{CO}_{2}$. For an instant, products like emissions of $\mathrm{SO}_{x}\left(\mathrm{SO}_{2}\right.$ and $\left.\mathrm{SO}_{3}\right)$ and $\mathrm{NO}_{x}\left(\mathrm{NO}\right.$ and $\left.\mathrm{NO}_{2}\right)$, causes acid rain, thus, turns to serious concern [2,7-9]. These product compounds contribute to the generation of sulfuric acid and nitric acid in oxide droplets in the environment. The above acids can precede both wet (e.g., by droplets) and dry (attached to solids accumulated on Earth), causing acidification of water and soil $[10,11]$.

However, bioenergy sources such as animal and agricultural waste, urban solid waste and wastewater waste as alternative energy sources have recently gained attention and considered an effective mechanism of repairing ecosystem [12,13]. Biomass (wood, charcoal, crop residues, and animal dung) and coal are used by almost 3 billion people worldwide as their primary energy source for cooking, lighting and other household purposes, including food processing $[1,14]$. In many developed countries, biomass accounts for more than half of household electricity, and about $90 \%$ in some lower-income countries as illustrated in Figure 1. Biofuels are derived from renewable energy resources and be non-polluting, but non-renewable energy and pollutant fuels are classified as fossil fuels. However, some biomass burning is also known as an environmental source of pollution, adding up to $40 \%$ of aggregate carbon dioxide and $38 \%$ of tropospheric ozone $[15,16]$. But if well treated or adopting some of the flameless combustion techniques shows emission-free $[17,18]$. Normally, both gaseous and liquid fuels, primarily derived from biomass like; bio-ethanol, biodiesel, bio-methanol, and bio-hydrogen are classified as biofuels $[19,20]$. Biogas is the biofuel that is most impressive. It is now more directly available, has good storage stability, has improved capacity, and are more flexibly implemented. It also can be derived from different biomass raw materials through fermentation processes, pyrolysis, or gasification approaches [21-23]. As alternatives to petroleum-based oils, liquid biofuels and biogas are applicable in IC engines or fuel cells. Converting biomass to electricity is similar to the conversion of coal to electricity using the combined cycle technique of either direct combustion or advanced gasification $[9,22]$.

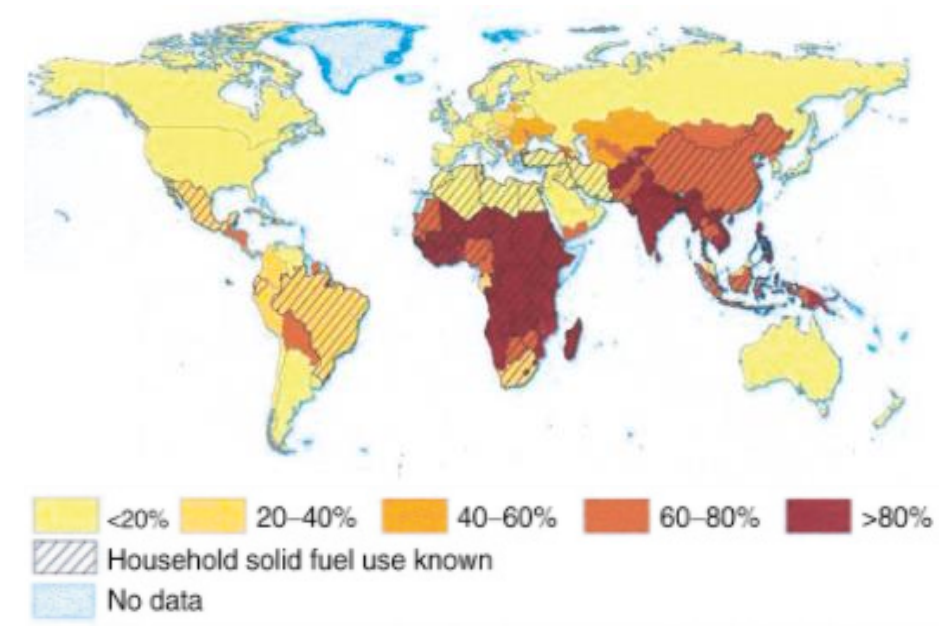

Fig. 1. Household electricity, and about $90 \%$ in some lowerincome countries [24]

\section{Bio-Fuel Sources/Production}

Biofuels may refer to fuels that are used for the generation of electricity, but they usually refer to liquid fuels that are used for transport $[18,25]$. Biomass fuels or biofuels belong to chemical energy stored by photosynthesis within plants. Feasibly, photosynthesis could transform $6.7 \%$ of the solar energy production on land into chemical energy, although only $0.3 \%$ is retained as carbon 
compounds in land plants on average [26]. Bioethanol synthesized from carbohydrates and biodiesel (ester) derived from fats and oils is currently the most popular fuels [27]. While ethanol is obtained from starch and sugars, it makes a good impact from the perspective of protecting the natural environment. Ethanol, produced from herbaceous and woody plants, agricultural and forest residues and vast amounts of urban and industrial waste, is derived from cellulose biomass $[12,21,28]$. However, starch and sugar represent a modest quantity of plant content, most of the biomass is represented by cellulose and hemicellulose, which are polymers of sugar molecules $[1,4,29]$. Generally, biomass for bio-fuel production can be group into two categories as in Figure 2.

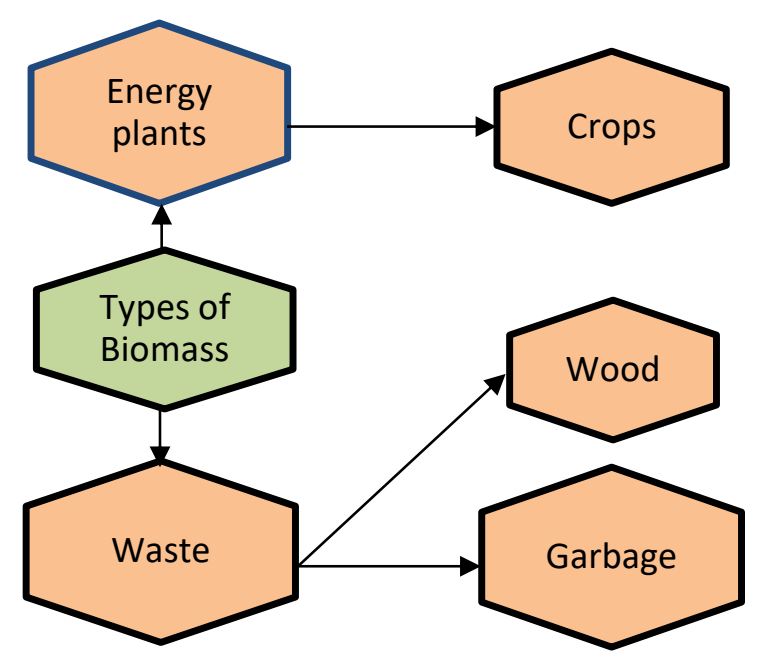

Fig. 2. Main sources of biomass for the production of bio-fuel

Many crops are cultivated primarily for their value as fuel. Many crops can easily be used as sources of energy. Any matter collected from commercial or residential land, such as food waste, paper, is organic municipal solid waste (MSW) or garbage $[12,30]$. Wood is perhaps the most widely used biomass for heat and fuel and unused woody waste is a by-product of many forestry activities [21]. Slade et al., [5] presented an overview of different findings regarding the availability of biomass globally both in the near and further future. The conclusion of the report is described in Figure 3 . The illustration shows that biomass can make a significant contribution to the supply of primary energy, but the magnitude of the trading volume depends on factors such as population growth, nutritional advancement and the associated development of meat-producing farming practices, changes in sustainable agriculture and forestry principles, and residue use [31,32]. 


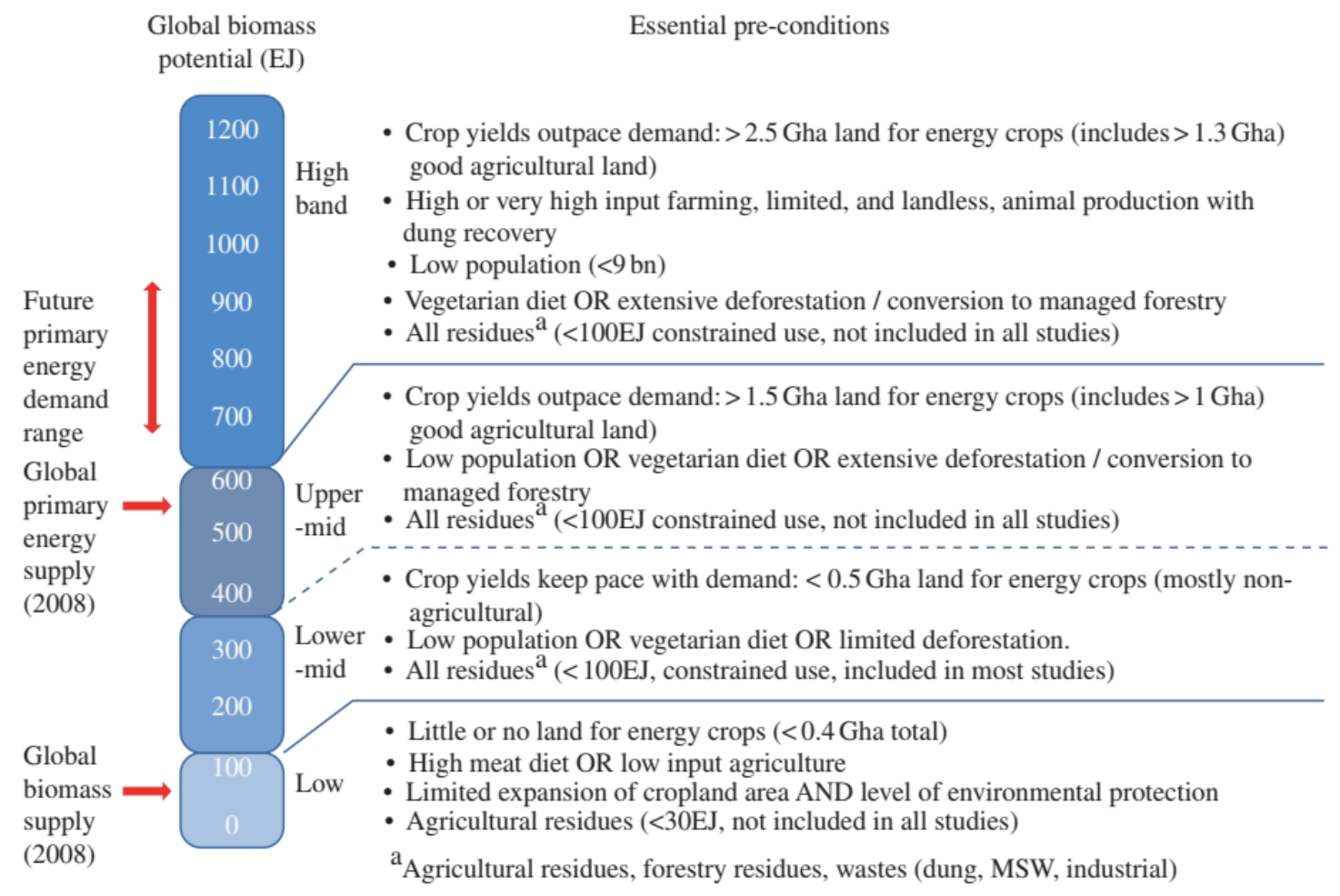

Fig. 3. Biomass potential as a fundamental energy source $[5,33]$

\section{Structural Constituents of Biomass}

The composition of biomass for bio-fuels is correlated with a multitude of physical characteristics, but belonging to the group of plants, constitutes cellulose, hemicellulose and lignin as the main structural cell wall components as shown in Figure 4 [4,29,30]. Besides, Starch (e.g., corn, banana, etc.) and chitosan are other significant bio-organic polymer structures that occur in nature $[12,34]$. The benefits and challenges from the utilization of biomass (biofuel) are listed in Table 1.

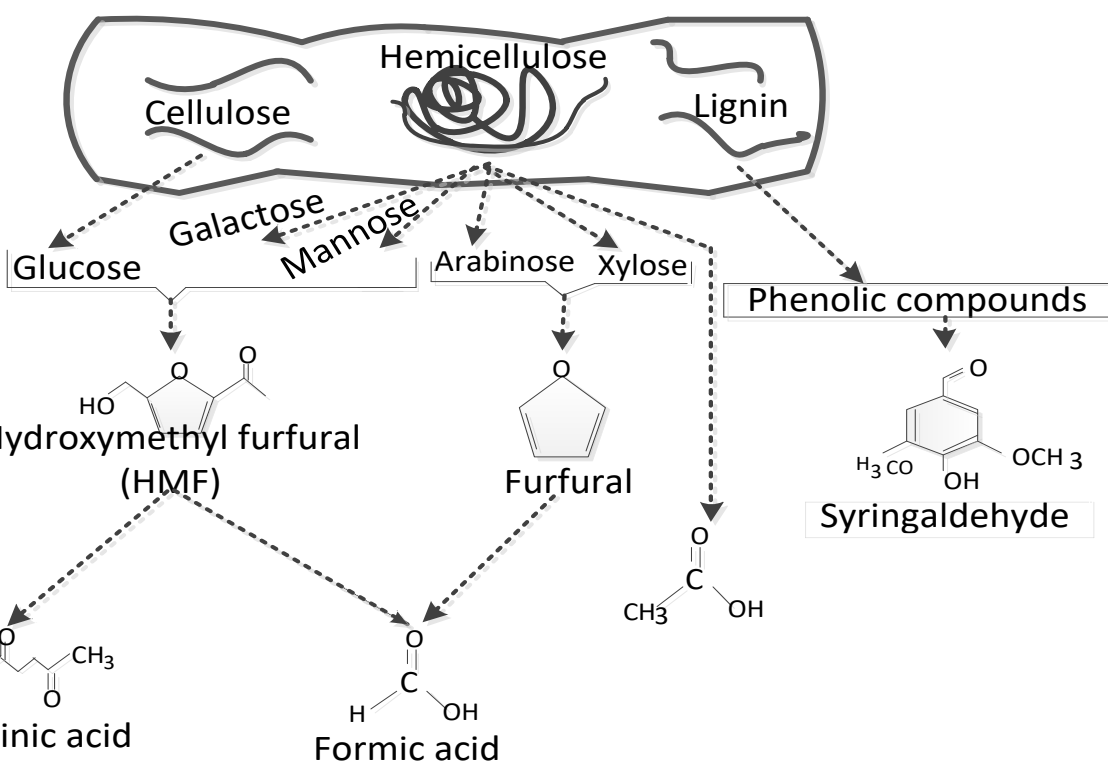

Fig. 4. Main constituents of biomass for biofuel production [4] 


\section{Table 1}

The benefits and challenges associated with bioenergy production [1,41-44]

Benefit
of energy that possesses fossil properties, capable to
control excessive emissions. Besides, non-scarce
substances are being used for extracting energy
from biomass. In comparison, many other major
renewable energy sources use uncommon materials
to create the necessary devices for power
generation.
As a relatively constant source of supply, biomass is
accessible as it can be retained under some
biomass-specific constraints, so it can serve as a
"natural battery." This would be relevant in terms of
ensuring the protection of the energy supply. On the
other hand, solar and wind energy are accessible as
varying sources in which the utilization of biomass is
still an area of growth.

Biomass is an excess of solar energy collected and is also used indirectly.

Since biomass is produced (indirectly) on a relatively short time scale by $\mathrm{CO}_{2}$ and water photosynthesis, which would also be released in energy conversion systems, one can technically speak of a "carbonneutral" fuel.

Biomass cultivation, processing, transport and storage, trade and refining for final use for energy conversion applications will boost rural economic growth more than that in the fossil fuel processing sector by generating additional employment. The latter contributes to increased income for both developed rural regions of the and finally provides a way to combat the persistent depopulation of such regions

\section{Challenges}

Compared with fossil fuels, biomass is characterised by a low energy density that threatens logistics. As a result, there is a minimal productive supply of biomass and, thus, it can only partially (but still substantially) lead to world energy consumption.

Though biomass is indeed renewable, they are widely used during the entire life cycle to produce fertilisers, pesticide, and eventually upgrade it to an actual fuel. Biofuels thus do have a fossil carbon footprint to a certain degree.

Habitat destruction issues characterized by severe loss of biodiversity and carbon stocks can arise if energy plantations are carried out at the cost of, for example, tropical rain forests.

A downside to using biomass as a natural source of energy will be the destruction of productive work (exergy). Using biomass as a source for chemical synthesis could be more effective from the point of view of a power system.

In general, the conversion of biomass materials into biofuels is low, indicating that relatively large surfaces are required to harvest sufficient material for energy conversion applications.

\subsection{Cellulose}

Cellulose is a glucose $\mathrm{C}_{6}$ sugar (hexosan) homopolysaccharide $\left(\mathrm{C}_{6} \mathrm{H}_{10} \mathrm{O}_{5}\right) \mathrm{n}$ that represents the main component of cell walls of plants, formed the world's source of organic materials $[1,4,30]$. It is integrated naturally with fibrous material such as kapok and cotton, forms the raw material for many industrial goods, such as paper, chipboard, mohair, bubble wrap. The bulk of biomass content consists of around 40-50 wt.\% cellulose on a dry fuel basis. The cellulose arrangement nature comprises about 14,000 linear D-glucopyranoside units linked by $1: 4 \beta$-glycosidic linkages, thus contributing significantly to the properties of biofuels. It is a species with high molecular weight, with a molecular mass usually equal to $106 \mathrm{~kg} \mathrm{~mol}^{-1}$. The $\beta$-glycosidic associations are usually referred to as weak bonds that are easily broken and help to degrade the cellulose substrate $[12,29]$. Compared to hemicellulose and starch, this structure provides extremely high stability towards thermal and biochemical breakdown [30,35]. 


\section{2 Hemicellulose}

Hemicelluloses are heteropolysaccharides composed of cellulose-associated $C_{5}$ and $C_{6}$ sugars (hexosans, pentosans) contained in the cell wall domains of plant species. In-plant biomass, is the second most abundant bio-material component species, account for approximately $25-35 \%$ of dry wood, $28 \%$ of softwoods, and $35 \%$ of hardwoods $[1,4,36]$. Hemicelluloses operate as a material for frame bond strength in plant cell layers, binding the micelles and fibres of cellulose together. Hemicelluloses represent relatively tiny molecules containing residues of 50-200 monosaccharides and form linkages distinct from those in Cellulose, e.g., side groups (branches) of oligosaccharide connected to the polysaccharide skeleton and functional group of acetyl [29]. Further categorised in their structure by the form of the main monosaccharide (e.g., xylose, arabinose, mannose, and galactose). The groups that can be classified into xylans, glucomannans, and arabinogalactans are $D$ xylans, L-arabino-D-xylans, D-mannans, D-galactose-D-mannans, D-gluco-D-mannans and L-arabinoD-galactans [4,12]. The composition of hemicellulose varies in plant tissue and influences the property of bio-fuel obtained. Hemicelluloses, because of less stable intramolecular linkages, are quicker to decompose than cellulose, both thermo-chemically and biochemically [1].

\subsection{Lignin}

Lignin is an amorphous biomass component consisting of a dynamic and complex threedimensional matrix of aromatic substructures that offers durability and strength and forms the woody cell membranes of plants and the reinforcing material between them together with cellulose $[36,37]$. The bulk of biomass consists of 20-30 \% lignin, a growth-related process called lignification, which is deposited within cell spaces. It is possible to distinguish different functional groups in lignin, such as hydroxyl, carbonyl and methoxyl groups [36]. The complex cellular units are linked mainly by ether attachments, but carbon-to-carbon interconnections exist as well [21]. In plant biomass, lignin has many roles. In addition to its contribution to mechanical strength, it preserves biomaterial from attacks for some bacteria's, since it is not usually digested by animal enzymes, thus contributed to the excellent nature of biofuel products [12]. In thermal conversion (pyrolysis), lignin is fairly stable and has a significantly higher heating value (HHV) than carbohydrates [38-40].

\section{Bio-fuel Conversion Techniques Route from Biomass}

As stated above, biofuels are referred to as a broad bioenergy category based on different raw materials and supplied by various technologies $[4,26,45,46]$. Depending on the expecting product, biomass can be transformed via biological routes into liquid or gaseous fuel [37]. In choosing a particular conversion technique, many factors always taken into consideration and properties of the fuel like physiochemical characteristics seems essential aspect owing to their influential strength toward the performance of the fuel produced [30,32]. These biofuels include biogas, bio-ethanol, bio-hydrogen, biodiesel and other amounts of some synthetic products, as shown in Figure 5 [5]. 


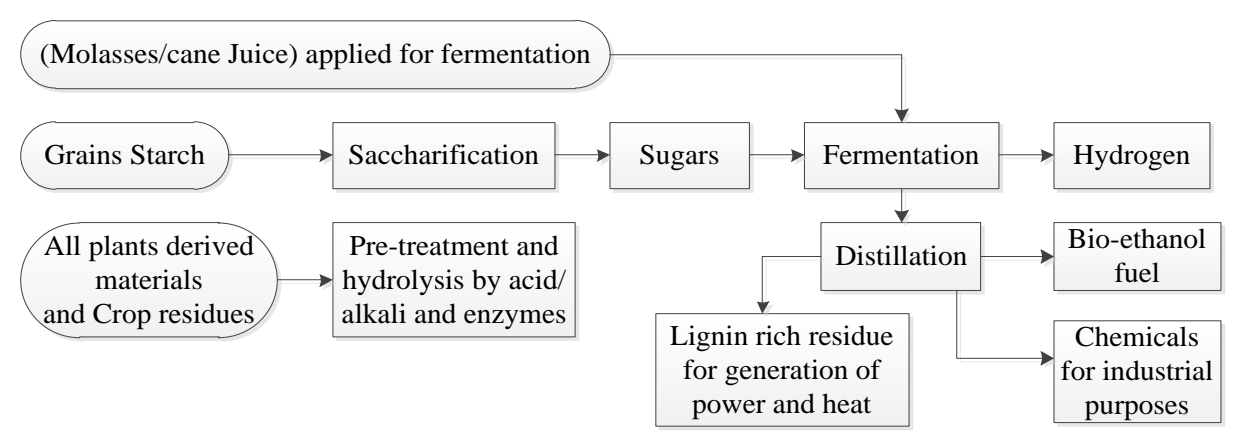

Fig. 5. Bio-fuel production process $[13,27,46]$

Natural resources possessing sugars or substances which can be processed into simple sugars could be used as fermentation substrates [37]. For example, beet molasses and cane, sugar cane, sugar beets and fruit juices are directly used commercially as fermentable products. As mentioned in section 3.0, lignocellulosic content consists of lignin, hemicellulose and pectin-embedded cellulose microfibrils with a modified proportion of each component between plant species and plant components, as listed in Table 2. Biomass conversion is more complex unlike simple sugar and starch since the first fermentable sugars need to be produced from lignocellulosic materials through hydrolysis [21,34]. The bio-ethanol processing process includes the extraction of fermentable sugars from polysaccharides, the refinement of extracted sugars, and the distillation process to separate bio-ethanol [27]. The bio-ethanol processing process involves the extraction of fermentable sugars from polysaccharides, the refinement of extracted sugars, and the distillation process to separate bio-ethanol. The suitable candidates for the production of bio-ethanol are well-known yeast bioethanol producers such as cerevisiae, Zymomonas mobilis and many other microorganisms such as Clostridium [26]. The total energy for biosynthesis release reactions generates 2 moles of bioethanol and $\mathrm{CO}_{2}$ per each mole of glucose consumed according to Eq. (1) [21]. Feasibly, 51.4g of bioethanol and $48.8 \mathrm{~g}$ of carbon dioxide would be generated from 100 grams of glucose [37].

$\mathrm{C}_{6} \mathrm{H}_{12} \mathrm{O}_{6} \rightarrow 2 \mathrm{C}_{2} \mathrm{H}_{5} \mathrm{OH}+2 \mathrm{CO}_{2}+$ energy (stored as ATP)

Where the Adenosine triphosphate (ATP) is the stored energy in organic material.

Table 2

Some essential composition (wt\%) of lignocellulosic biomass [12]

\begin{tabular}{llll}
\hline & Sugar beet pulp & Wheat straw & Bagasse \\
\hline Xylose & 18.2 & 19.2 & 22.1 \\
Glucose & 24.1 & 32.6 & 39.0 \\
Arabinose & 1.5 & 2.4 & 2.1 \\
Galactose & 0.9 & 0.8 & 0.5 \\
Mannose & 4.6 & 0.3 & 0.4 \\
Pentoses (C5) & - & - & - \\
Hexoses (C6) & - & - & - \\
Other constituents & 50.7 & 44.7 & 35.9 \\
\hline
\end{tabular}

Another possible green product, an alternative to fossil fuels is biodiesel derived from oil crops, animal, plant, adopting a process of transesterification $[47,48]$. Biodiesel is a biofuel composed of organic oils extracted from monoalkyl esters that as shown in Figure 6 . This is an ideal process where, in the presence of a catalyst and alkali such as potassium hydroxide, organic oil or triglyceride can be processed into biodiesel [49]. To fasting the reaction on biodiesel production, an excess of methanol is used [31]. 


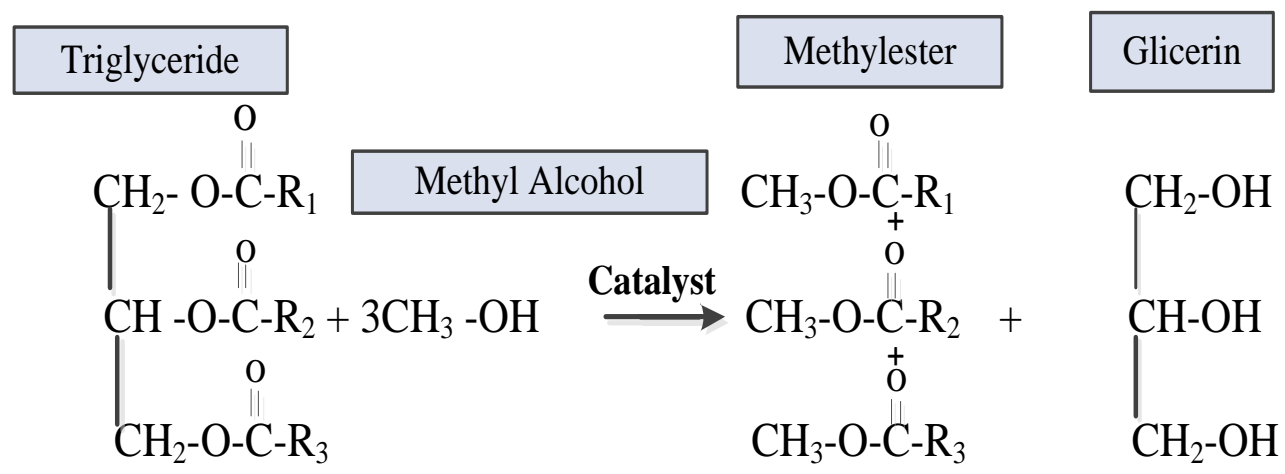

Fig. 6. Production of biodiesel using transesterification reaction $[25,49]$

\subsection{Chemical Reactions}

The biomass gasification process is characterized by many sub-processes like pyrolysis and gasification [28,50]. During gasification, many chemical reactions occur, which are summarized in Eq. (1)-(13) below [1,51]. In the reactions, carbonaceous residue called char mostly generated comprised of carbon (c) and tar as $\mathrm{C}_{n} \mathrm{H}_{\mathrm{m}}$. Devolatilization or pyrolysis is called the thermal decomposition of biomass and the creation of gaseous products during biomass particle heating $[5,28]$. The reaction is an endothermic process that occurs in the absence of oxygen, by definition [52]. Devolatilization of solid biomass begins with the thermal cracking of compounds at temperatures above $200^{\circ} \mathrm{C}$ [53]. Products like Tars, liquids and gaseous products are formed at Up to $600^{\circ} \mathrm{C}$ temperatures $[32,54]$. However, the tars formation can be reduced through the application of some catalyst via the technique of in situ removal within the gasifier (primary methods) and downstream the gasifier (secondary approach) as shown in Figure 7, while Figure 8 described the thermochemical technique of conversion of biomass through gasification $[5,46]$.

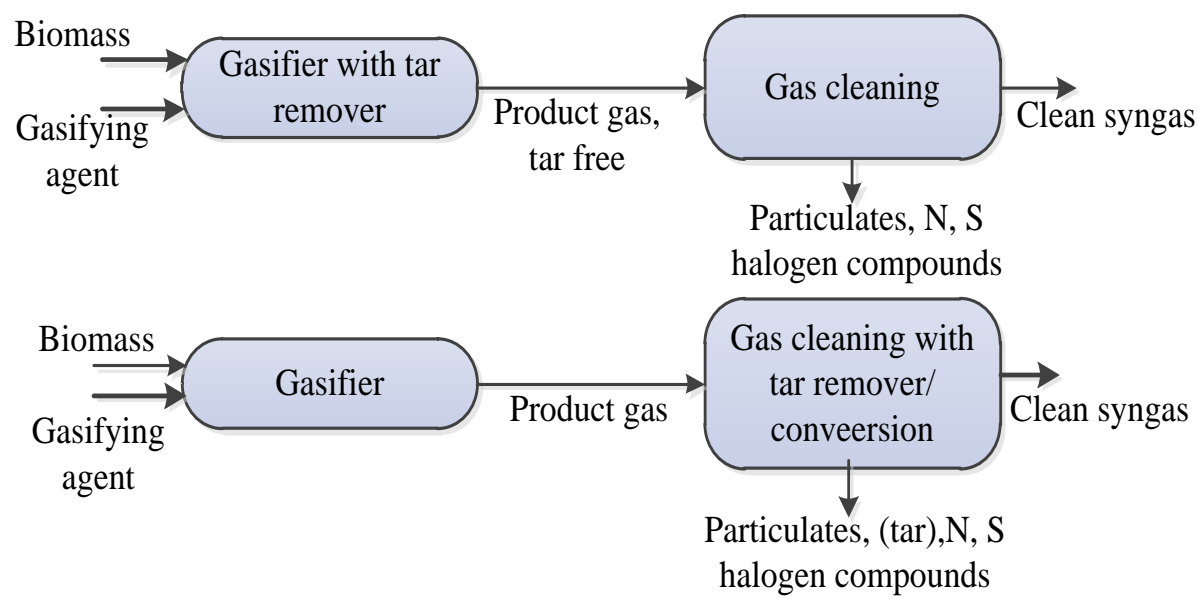

Fig. 7. Approaches in reducing tar formation using the primary method and secondary approach $[25,55]$

The volatile gas mixture consists of methane $\left(\mathrm{CH}_{4}\right)$, carbon monoxide $(\mathrm{CO})$, carbon dioxide $\left(\mathrm{CO}_{2}\right)$, as well as other hydrocarbon gases like $\mathrm{C}_{2} \mathrm{H}_{2}, \mathrm{C}_{2} \mathrm{H}_{4}$, and $\mathrm{C}_{2} \mathrm{H}_{6}$, further illustrate the formation processes with the heat involved in Eq. (2)-(14) [51]. 


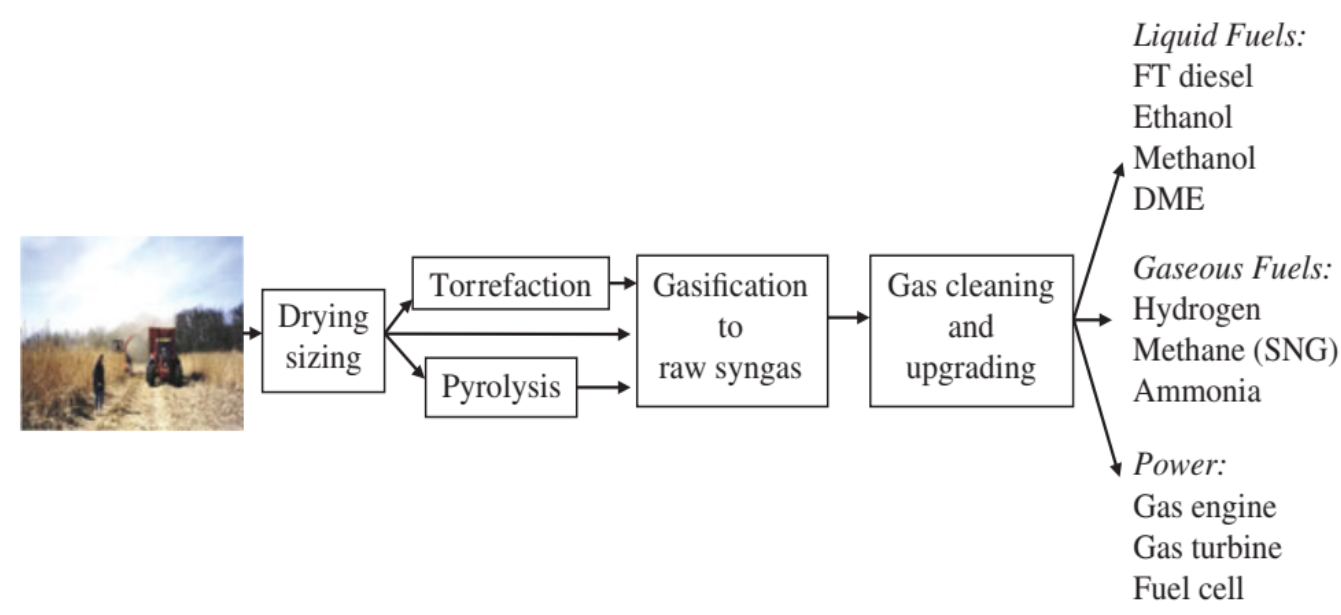

Fig. 8. The thermochemical technique of conversion of biomass through gasification with multiple products $[22,51,52]$

$$
\begin{aligned}
& C(s)+\mathrm{O}_{2} \rightarrow \mathrm{CO}_{2} \quad \Delta_{r} \mathrm{H}_{298}^{O}=-394 \mathrm{~kJ} \cdot \mathrm{mol}^{-1} \\
& C(s)+1 / 2 O_{2} \rightarrow C O \quad \Delta_{r} H_{298}^{O}=-111 k J \cdot \mathrm{mol}^{-1} \\
& C(s)+H_{2} \mathrm{O} \leftrightarrow \mathrm{CO}+\mathrm{H}_{2} \Delta_{r} H_{298}^{O}=+131 \mathrm{~kJ} \cdot \mathrm{mol}^{-1} \\
& C(s)+\mathrm{CO}_{2} \leftrightarrow 2 \mathrm{CO} \quad \Delta_{r} H_{298}^{O}=+173 \mathrm{~kJ} \cdot \mathrm{mol}^{-1} \\
& C(s)+2 H_{2} \leftrightarrow \mathrm{CH}_{4} \quad \Delta_{r} H_{298}^{O}=-75 \mathrm{~kJ} \cdot \mathrm{mol}^{-1} \\
& C(s)+1 / 2 \mathrm{O}_{2} \rightarrow \mathrm{CO}_{2} \quad \Delta_{r} \mathrm{H}_{298}^{O}=-283 \mathrm{~kJ} \cdot \mathrm{mol}^{-1} \\
& \mathrm{H}_{2}+1 / 2 \mathrm{O}_{2} \rightarrow \mathrm{H}_{2} \mathrm{O} \quad \Delta_{r} H_{298}^{O}=-242 \mathrm{~kJ} \cdot \mathrm{mol}^{-1} \\
& \mathrm{CO}+\mathrm{H}_{2} \mathrm{O} \rightarrow \mathrm{CO}_{2}+\mathrm{H}_{2} \quad \Delta_{r} \mathrm{H}_{298}^{O}=-41 \mathrm{~kJ} \cdot \mathrm{mol}^{-1} \\
& \mathrm{CH}_{4}+\mathrm{H}_{2} \mathrm{O} \rightarrow \mathrm{CO}+3 \mathrm{H}_{2} \Delta_{r} \mathrm{H}_{298}^{O}=+206 \mathrm{~kJ} \cdot \mathrm{mol}^{-1} \\
& C_{n} H_{m}(\text { tars })+n H_{2} \mathrm{O} \rightarrow n C O+(n+m / 2) H_{2} \\
& C_{n} \mathrm{H}_{m}(\text { tars })+n \mathrm{CO}_{2} \leftrightarrow 2 n \mathrm{CO}+m / 2 \mathrm{H}_{2} \\
& C_{n} H_{m}(\text { tars }) \leftrightarrow n C+(n+m / 2) H_{2} \\
& C_{n} H_{m}(\operatorname{tars})+(4 n-m) / 2 \mathrm{H}_{2} \mathrm{O} \leftrightarrow n C \mathrm{H}_{4}
\end{aligned}
$$

Through exothermic partial oxidation (auto-thermal operation) or indirectly through the integration of the reaction process with the external exothermic process, which transfers heat to the main gasification reactor, the supply of heat to complete the main endothermic gas-generating reactions may be provided in situ [56]. During the mechanism of the hydrothermal condition of biomass conversion, the biomass gasification with supercritical water is a result of thermal 
decomposition reactions, yielding homogeneous reactions with the forming gases [28]. The overall process equation (for glucose) is expressed in Eq. (15)-(17) [26,32];

$u \mathrm{C}_{6} \mathrm{H}_{12} \mathrm{O}_{6}+\mathrm{v} \mathrm{H}_{2} \mathrm{O} \rightarrow w \mathrm{CO}_{2}+x \mathrm{CH}_{4}+y \mathrm{CO}+z \mathrm{H}_{2}$

For the formation of complete hydrogen product;

$\mathrm{C}_{6} \mathrm{H}_{12} \mathrm{O}_{2}+6 \mathrm{H}_{2} \mathrm{O} \rightarrow 6 \mathrm{CO}_{2}+12 \mathrm{H}_{2}$

For maximum methane formation;

$\mathrm{C}_{6} \mathrm{H}_{12} \mathrm{O}_{6} \rightarrow 3 \mathrm{CH}_{4}+3 \mathrm{CO}_{2}$

\section{Sustainability Impact of Bio-fuel}

The general conflict on limitations of the availability of oil in the mid-1970s gave rise to the first eagerness to support biomass for the supply of fuel as well as other types of renewable energy, also with the first oil crisis and environmental issues [41]. However, due to the oil crisis, fossil fuel prices dropped again because of their higher supply, hampering the further growth of bioenergy advancement [31,57]. The fear arose in the 1980s and 1990s that global warming and the subsequent climate change were boosted by $\mathrm{CO}_{2}$ emissions. The Kyoto Protocol (UNFCCC, 1997), centred on the Emissions reduction from fossil fuels and stimulated research in the field of renewables, in particular biomass, as one of the main sources of carbon mitigation [3]. With the change from the present energy system dependent on fossil fuels, it is anticipated that a sustainable bio-based energy system will be dispersed and require a complex combination of fossil and renewable sources of energy $[26,50]$. A global concept of sustainability is a "development that meets the needs of the present without compromising the ability of future generations to meet their own needs $[1,2,54]$. Base on the concept, the sustainability impact was classified into socioeconomic impact and ecological implications associated with the utilization of biomass/biofuel products $[2,54]$.

\subsection{Socioeconomic Consideration}

Economic growth depends on a stable supply of electricity. The price evolution of renewable fuels, in this case, centred on biofuels. Investments to be made in the capital for process equipment and facilities, as well as the requisite human capital, are the costs associated with the implementation of bioenergy technologies $[9,33,58]$. Moreover, in terms of economic parameters, permissible financing schemes in countries promoting bioenergy technologies are essential for sustainable development $[43,59]$. There is indeed a broad debate globally on the quality of biomass products and related activities in the field of certification, which defines supply and therefore pricing. Eventually, countries started to use taxes for importing and exporting biomass materials, which create exchange barriers that affect the economics of the supply of bioenergy, as well as affecting the production of biomass by countries with wide export potential $[9,27,31]$. Another significant element of sustainability is social impact. Food is of primary importance to life and this must not be threatened by biomass-growing systems. The labour opportunities offered in the field of growing and using biomass for the supply of energy will make a significant contribution to jobs that are of social benefit to humanity [2]. 


\subsection{Ecological Considerations}

Concerning the environmental effects, the key emphasis of the implementation of biofuels is the GHG footprint as referred to in section 1. Acceptability in terms of sustainable bioenergy production is determined not only by GHG but also by other air pollution. This concerns, for example, the precursors of acid rain, NOx and SOx [60-62]. In biomass, sulphur and other poisonous emissions formation are very minimal and can be controlled to zero levels using some flameless combustion mode (exhaust gas recirculation and application of catalyst [63-65]. Furthermore, the availability of nutrients and the harvest of biomass contribute to ensuring that agricultural practice can be continued, it should be held in equilibrium. Finally, biodiversity conservation should be valued so that the risk of failure by pests and diseases to which single crops may be exposed does not run also, a diverse ecosystem should also be ensured for the flourishing of human beings, flora and fauna $[9,33]$. Although intermediate reaction products $\left(\mathrm{CO}, \mathrm{CH}_{4}\right.$, particles Volatile organic compounds (VOCs) and others) leave the reactor as part of the flue gas when the biomass is not fully oxidised into its final products. Therefore, $\mathrm{CO}$ emissions can be viewed as a reasonable measure of how complete the combustion performed. The rate at which $\mathrm{CO}$ is oxidised to $\mathrm{CO}_{2}$ depends primarily on temperature if oxygen is available [24].

\section{Physiochemical Characteristics of the Biomass Samples (Bio-Fuel)}

Characterizing the composition of a given fuel (fossil and biofuel) can only be achieved utilizing two standard analyses, the proximate and the ultimate analysis, which is common practice, with their compositions listed in Table 3.

\subsection{Proximate Analysis}

To evaluate the constituent groups (Moisture content, Ash content, volatile matter content) in the gasoline, the proximate analysis is used. Moisture is one of the main components of biomass, and this also makes a crucial difference with coals [66]. High moisture levels can have a significant effect on thermal conversion as well as fuel nature, and either drying or water conversion techniques should be used [50]. For volatile matter content, the biomass sample is heated ('carbonised') in a coated crucible to $550^{\circ} \mathrm{C}$ (for coals to $900^{\circ} \mathrm{C}$ ) in an inert environment. Biomass can contain substantial volatile alkali substance quantities and also carbonates that can break down at temperatures above $600^{\circ} \mathrm{C}$, which limits biomass temperature. The more volatile fuel fractions are emitted as a complicated mixture of gases and vapours under these conditions. Ash melting (slagging) creates serious problems in biomass thermochemical processing systems, like an agglomeration of reactor contents and heat exchanger slagging, with negative consequences for safe and efficient reactor operation and heat application [32,54,67]. The ash content and the behaviour of ash melting are also significant properties of solid biomass fuels $[66,67]$. Some of the physical-chemical properties of the biomass samples.

\subsection{Ultimate Analysis}

The chemical composition and the HHV of the fuel are given in the ultimate (or elementary) analysis [66]. This analysis generally lists the fuel's oxygen, carbon, hydrogen, sulphur, nitrogen, and ash content on a percentage basis by weight (see Table 3 ). Remember that biomass typically has very low levels of nitrogen and sulphur compared to fossil fuels (mostly coal) [50]. The heating value (also 
referred to as the calorific value) is a calculation of the thermal energy released after complete combustion and is a key feature for deciding energy balances and measuring the flame temperature for thermodynamic conversions such as burning. The HHV recognizes the water that was readily available as humidity in the liquid form, as well as the water chemically derived from the fuel-bound $\mathrm{H}$ material [50]. The LHV, on the other hand, suggests that all water forms exist in the vapour phase.

\section{Table 3}

Some of the Biomass samples physical-chemical properties [68]

\begin{tabular}{|c|c|c|c|c|c|c|c|c|c|}
\hline \multicolumn{6}{|c|}{ Ultimate Analysis (wt\% on wet basis) } & \multicolumn{4}{|c|}{ Proximate Analysis } \\
\hline Biomass & C & $\mathrm{N}$ & $\mathrm{O}$ & $\mathrm{H}$ & $\mathrm{S}$ & Moisture (\%) & $(\mathrm{VM}+\mathrm{FC})(\%)$ & Ash (\%) & $\mathrm{HHV}\left(\mathrm{MJkg}^{-1}\right)$ \\
\hline $\begin{array}{l}\text { Pine } \\
\text { sawdust }\end{array}$ & 45.95 & 0.32 & 34.32 & 7.47 & 0.57 & 608.44 & 116188.37 & 624.71 & $6317 \pm 0.07$ \\
\hline $\begin{array}{l}\text { Sugar } \\
\text { cane }\end{array}$ & 45.06 & 0.25 & 37.91 & 5.57 & - & 306.95 & 3189.82 & 323.21 & $3317 \pm 0.07$ \\
\hline $\begin{array}{l}\text { Rice } \\
\text { Husk }\end{array}$ & 31.47 & 1.04 & 23.03 & 6.67 & 0.50 & 508.19 & 5161.68 & 5229.53 & 53 15. 39 \pm 0.01 \\
\hline $\begin{array}{l}\text { Peanut } \\
\text { shell }\end{array}$ & 41.52 & 2.12 & 27.96 & 7.43 & 0.60 & 407.98 & 4179.10 & 4212.80 & $4316.52 \pm 0.03$ \\
\hline $\begin{array}{l}\text { Tucuma } \\
\text { seed }\end{array}$ & 48.83 & 0.88 & 32.20 & 6.12 & - & 206.08 & 2188.18 & 225.97 & $23 \quad 20.77 \pm 0.07$ \\
\hline $\begin{array}{l}\text { Coffee } \\
\text { husk }\end{array}$ & 43.13 & 1.55 & 32.78 & 5.02 & 0.67 & 108.44 & 1182.54 & 127.40 & $13 \quad 16.797 \pm 0.07$ \\
\hline
\end{tabular}

\section{Exhaust Emission Reduction from Bio-fuels}

Bioethanol is a relative quality fuel that can minimise air pollution and increase the efficiency of vehicles. The properties of bio-ethanol mean that it improves the amount of octane as an additive, decreases emissions and is cleaner for the environment than gasoline and diesel [50]. The emissions of bio-ethanol blends are reduced by up to $10 \%$ (HC $18 \%$, CO $18 \%$, NOx $10 \%$ ) and do not present any problems. Because of the amount of oxygen in biomass, bio-fuel is referred to as "oxygenate" because it contains $34.7 \%$ oxygen by weight, which causes combustion of fuel and thus leads to exhaust pollution and petroleum use reduction, thus, bio-ethanol showed a $21 \%$ decrease in $\mathrm{CO}_{2}$ equivalent production when compared to $2.44 \mathrm{~kg} \mathrm{CO} 2$ equivalent/ litre gasoline production $[39,44]$. The area of biodiesel, contains much amount of cetane, little sulphur content and lesser aromatics, unlike conventional diesel fuel [17]. Emissions formulations are reduced due to the presence of oxygen in the fuel $[50,51]$. The current engines can use a $20 \%$ biodiesel blend with no alteration and reduction of torque output based on the content. On the side of biogas, taking from a greenhouse gas point of view, the production of biogas from animal waste is highly favourable, reducing the emission of methane and reducing the release of carbon dioxide, unlike fossil fuel $[50,63]$. There is still some threat to NOx emissions, but they remain below EU standards. Biogas is much greater than $\mathrm{NGV}$ in terms of $\mathrm{CO}_{2}$, hydrocarbons and $\mathrm{CO}$ emissions [39]. Also, in hydrogen fuel, biohydrogen is a renewable and clean energy fuel that, when combusted, creates water rather than greenhouse gases [69]. Hydrogen could be a pollution-free transportation fuel, depending on the energy source that induces the chemical reaction. Current government and industry scientific research investing to examine the safe and economical manufacture of hydrogen and hydrogen vehicles.

\subsection{Emission Control Through Flameless Mode}

During the flameless process, pollutant emissions were very low for both fuels (bio-fuel and natural gas); only residual values of $\mathrm{CO}$ and $\mathrm{NO}_{x}$ were calculated in the chimney. The mean pollutant 
emission level is shown in Figure 9. According to Bagheri et al., [70] findings, dilution of methane with inert gases such as $\mathrm{CO}_{2}$ by $40 \%$ (volumetric) has a negligible impact on pollutant emissions under the Flameless combustion regime in the furnace setting. Though this recirculation factor (Kv) could not be determined, the low emissions of NOx and $\mathrm{CO}$, the very uniform temperature profiles and the visual characteristics of the reaction volume were not consistent with those recorded in the stable range for flameless combustion $[60,71]$. When in Flameless mode, the device was fuelled with biogas, the loss of energy from hot combustion products $\left(851^{\circ} \mathrm{C}\right)$ via the chimney was $26 \%$ of the overall output of fumes, while $12.9 \%$ of the total energy input was projected [72]. On the other hand, $15 \%$ of the combustion products $\left(881^{\circ} \mathrm{C}\right)$ were evacuated through the chimney when the device was fuelled with natural gas in flameless mode, and energy losses via the chimney were $6.5 \%$ of the overall energy input [73].

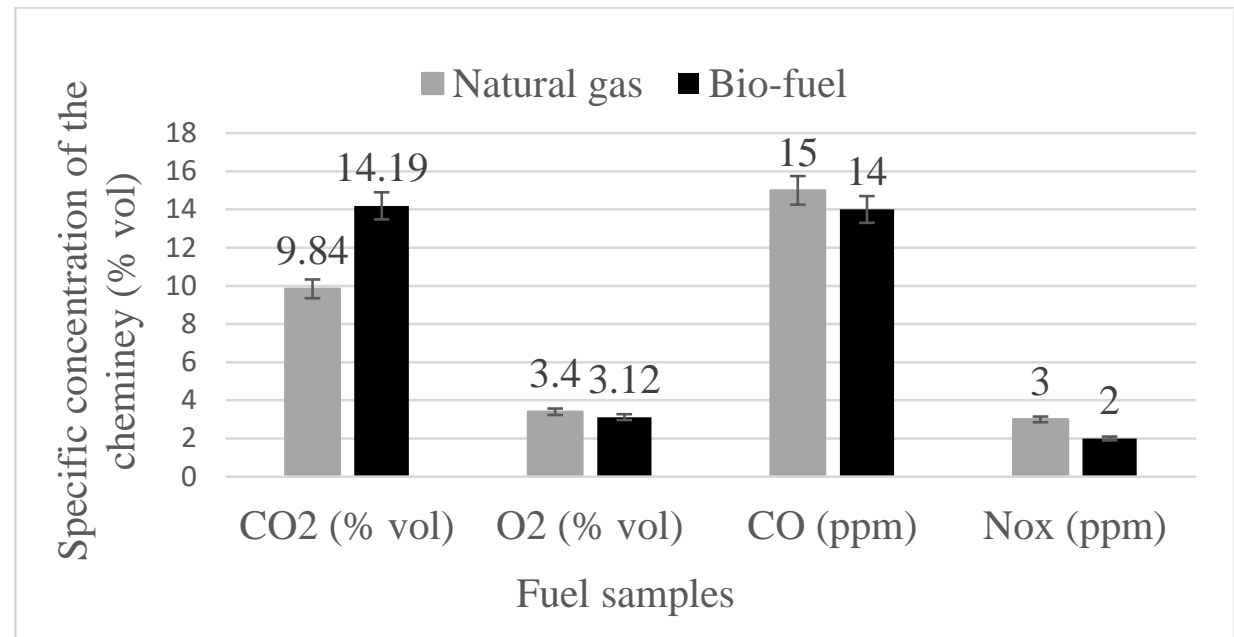

Fig. 9. The emission percentages on $\mathrm{CO}_{2}, \mathrm{O}_{2}, \mathrm{CO}$ and $\mathrm{NO}_{x}$ during Flameless mode [68]

When the device is fuelled with biogas, the higher energy losses through the chimney are due to the higher concentration of $\mathrm{CO}_{2}$, which has a higher potential for radiation heat absorption that enables it to absorb more heat from the system the region of reaction. When the burner was fuelled with biogas, the calculated regenerative efficiency was $85 \%$, while for natural gas it was $66 \%$, which explains the possibility of achieving a comparable global efficiency under the flameless combustion scheme for both types of fuel $[60,68]$.

\section{Conclusion}

The effect and increase of the depletion of fossil fuel resources and knowledge of environmental emissions from the combustion of petroleum indicate the need to find alternative renewable fuels for fossil substitute. In contrast with fossil, the most essential qualities of bio-fuel are their renewability and eco-friendly properties. Thorough studies have confirmed that biomass can be considered one of the major sources of biofuel and has a good prospect of producing biodiesel. Globally, the economy is progressing rapidly and economic growth relies on green and sustainable energy. The influence of non-renewable resources not only releases a significant quantity of greenhouse gases into the atmosphere but also diminishes day by day, raising the need to replace non-renewable resources with sustainable energy shortly. The introduction of innovative methods and different initiatives verified that renewable energy has been of significant benefit globally for the improvement of mankind. In addition to the low biofuel emissions due to the oxygen content, the 
efficiency of the furnace remained practically constant under the flameless combustion regime when burning biogas. $\mathrm{NO}_{\mathrm{x}}$ and $\mathrm{CO}$ emissions were very low in both cases, lower than $3 \mathrm{ppm}$ and $16 \mathrm{ppm}$, respectively. Although the efficiency was $2 \%$ lower when the device was fuelled with biogas, and a small reduction in the temperature area was observed. There were many advantages to the Flameless combustion process like a longer and dispersed reaction zone was discovered during service in flameless mode, the temperature profile was also more consistent, and the performance of the system was greater due to the use of regenerative honeycombs.

\section{References}

[1] De Jong, Wiebren, and J. Ruud van Ommen. Biomass as a sustainable energy source for the future: fundamentals of conversion processes. John Wiley \& Sons, 2014. https://doi.org/10.1002/9781118916643

[2] Panwar, N. L., S. C. Kaushik, and Surendra Kothari. "Role of renewable energy sources in environmental protection: A review." Renewable and Sustainable Energy Reviews 15, no. 3 (2011): 1513-1524. https://doi.org/10.1016/i.rser.2010.11.037

[3] United Nations. The adoption of the kyoto protocol of the united nations framework convention on climate change. United Nations Climate Change, 1998.

[4] Opia, Anthony Chukwunonso, Mohd Kameil Bin Abdul Hamid, Samion Syahrullail, Abu Bakar Abd Rahim, and Charles AN Johnson. "Biomass as a potential source of sustainable fuel, chemical and tribological materialsOverview." Materials Today: Proceedings 39 (2021): 922-928. https://doi.org/10.1016/i.matpr.2020.04.045

[5] Slade, Raphael, Robert Saunders, Robert Gross, and A. Bauen. "Energy from biomass: the size of the global resource." UK Energy Research Centre (2011).

[6] Khattak, Muhammad Adil, Mohammad Azfar Haziq Ayoub, Muhammad Ariff Fadhlillah Abdul Manaf, Mohd Faidhi Mahru, Mohd Ridwan Mohd Juhari, Mira Idora Mustaffa, and Suhail Kazi. "Global energy security and European Union: A review." Journal of Advanced Research in Applied Sciences and Engineering Technology 11, no. 1 (2018): 64-81.

[7] Arghode, Vaibhav K., Ashwani K. Gupta, and Kenneth M. Bryden. "High intensity colorless distributed combustion for ultra low emissions and enhanced performance." Applied Energy 92 (2012): 822-830. https://doi.org/10.1016/j.apenergy.2011.08.039

[8] Zhu, Shu-Jun, Qing-Gang Lyu, Jian-Guo Zhu, and Jia-Rong Li. "NO emissions under pulverized char MILD combustion in $02 / \mathrm{CO} 2$ preheated by a circulating fluidized bed: Effect of oxygen-staging gas distribution." Fuel Processing Technology 182 (2018): 104-112. https://doi.org/10.1016/i.fuproc.2018.09.002

[9] Dale, Bruce E., and Seungdo Kim. "Biomass refining global impact-the biobased economy of the 21st century." Biorefineries-Industrial Processes and Products: Status Quo and Future Directions (2005): 41-66. https://doi.org/10.1002/9783527619849.ch2

[10] Abuelnuor, A. A. A., M. A. Wahid, H. A. Mohammed, and A. Saat. "Flameless combustion role in the mitigation of NOX emission: a review." International Journal of Energy Research 38, no. 7 (2014): 827-846. https://doi.org/10.1002/er.3167

[11] Fortunato, Valentina, Gabriele Mosca, Delphine Lupant, and Alessandro Parente. "Validation of a reduced NO formation mechanism on a flameless furnace fed with $\mathrm{H} 2$-enriched low calorific value fuels." Applied Thermal Engineering 144 (2018): 877-889. https://doi.org/10.1016/i.applthermaleng.2018.08.091

[12] Vassilev, Stanislav V., David Baxter, Lars K. Andersen, and Christina G. Vassileva. "An overview of the chemical composition of biomass." Fuel 89, no. 5 (2010): 913-933. https://doi.org/10.1016/i.fuel.2009.10.022

[13] Gupta, Priyanka, Raj Shekhar Singh, Ashish Sachan, Ambarish S. Vidyarthi, and Asha Gupta. "Study on biogas production by anaerobic digestion of garden-waste." Fuel 95 (2012): 495-498. https://doi.org/10.1016/j.fuel.2011.11.006

[14] Yacob, Noraishah Shafiqah, Hassan Mohamed, and Abd Halim Shamsuddin. "Investigation of Palm Oil Wastes Characteristics for Co-Firing with Coal." Journal of Advanced Research in Applied Sciences and Engineering Technology 23, no. 1 (2021): 34-42. https://doi.org/10.37934/araset.23.1.3442

[15] Bowman, Craig T. "Control of combustion-generated nitrogen oxide emissions: technology driven by regulation." In Symposium (International) on Combustion, vol. 24, no. 1, pp. 859-878. Elsevier, 1992. https://doi.org/10.1016/S0082-0784(06)80104-9

[16] Gupta, Ashwani, and Toshiaki Hasegawa. "The effect of air preheat temperature and oxygen concentration in air on the structure of propane air diffusion flames." In 37th Aerospace Sciences Meeting and Exhibit, p. 725. 1999. https://doi.org/10.2514/6.1999-725

[17] Khan, Atif Ahmed, Martti Aho, Wiebren de Jong, Pasi Vainikka, Peter Johannes Jansens, and Hartmut Spliethoff. 
"Scale-up study on combustibility and emission formation with two biomass fuels (B quality wood and pepper plant residue) under BFB conditions." Biomass and Bioenergy 32, no. 12 (2008): 1311-1321. https://doi.org/10.1016/j.biombioe.2008.03.011

[18] Enagi, Ibrahim I., K. A. Al-Attab, and Z. A. Zainal. "Liquid biofuels utilization for gas turbines: a review." Renewable and Sustainable Energy Reviews 90 (2018): 43-55. https://doi.org/10.1016/j.rser.2018.03.006

[19] Marchetti, Cesare. "Primary energy substitution models: on the interaction between energy and society." Technological Forecasting and Social Change 10, no. 4 (1977): 345-356. https://doi.org/10.1016/00401625(77)90031-2

[20] Farhana, K., K. Kadirgama, D. Ramasamy, M. Samykano, and G. Najafi. "Experimental Studies on Thermo-Physical Properties of Nanocellulose-Aqueous Ethylene Glycol Nanofluids." Journal of Advanced Research in Materials Science 69, no. 1 (2020): 1-15. https://doi.org/10.37934/arms.69.1.115

[21] Mohan, Dinesh, Charles U. Pittman Jr, and Philip H. Steele. "Pyrolysis of wood/biomass for bio-oil: a critical review." Energy \& Fuels 20, no. 3 (2006): 848-889. https://doi.org/10.1021/ef0502397

[22] Grassi, G., A. Collina, and H. Zibetta. "Thermochemical Conversion Processes: Posters." In Biomass for Energy, Industry and Environment, pp. 755-922. CRC Press, 2003. https://doi.org/10.1201/9781482286748-18

[23] Geoprincy, G., BN Vidhya Srri, U. Poonguzhali, N. Nagendra Gandhi, and S. Renganathan. "A review on green synthesis of silver nanoparticles." Asian Journal of Pharmaceutical and Clinical Research 6, no. 1 (2013): 8-12.

[24] Hosseini, Seyed Ehsan, and Mazlan Abdul Wahid. "Feasibility study of biogas production and utilization as a source of renewable energy in Malaysia." Renewable and Sustainable Energy Reviews 19 (2013): 454-462. https://doi.org/10.1016/j.rser.2012.11.008

[25] Demirbas, Ayhan. "Biofuels securing the planet's future energy needs." Energy Conversion and Management 50, no. 9 (2009): 2239-2249. https://doi.org/10.1016/i.enconman.2009.05.010

[26] McKendry, P. "Energy production from biomass (part 1): Overview of biomass." Bioresour Technol 83 (2002): $37-$ 46. https://doi.org/10.1016/S0960-8524(01)00118-3

[27] Veza, Ibham, Mohd Farid Muhammad Said, and Zulkarnain Abdul Latiff. "Progress of acetone-butanol-ethanol (ABE) as biofuel in gasoline and diesel engine: A review." Fuel Processing Technology 196 (2019): 106179. https://doi.org/10.1016/i.fuproc.2019.106179

[28] Biermann, Ursula, Wolfgang Friedt, Siegmund Lang, Wilfried Lühs, Guido Machmüller, Uurgen O. Metzger, Mark Rüsch Gen. Klaas, Hans J. Schäfer, and Manfred P. Schneider. "New Syntheses with Oils and Fats as Renewable Raw Materials for the Chemical Industry." Biorefineries-Industrial Processes and Products: Status Quo and Future Directions (2005): 253-289.

[29] Jacobsen, Sigrid E., and Charles E. Wyman. "Cellulose and hemicellulose hydrolysis models for application to current and novel pretreatment processes." Applied Biochemistry and Biotechnology 1, no. 84-86 (2000): 81-96. https://doi.org/10.1385/ABAB:84-86:1-9:81

[30] Varma, Rajender S. "Biomass-derived renewable carbonaceous materials for sustainable chemical and environmental applications." ACS Sustainable Chemistry \& Engineering 7, no. 7 (2019): 6458-6470. https://doi.org/10.1021/acssuschemeng.8b06550

[31] Hosseini, Seyed Ehsan, and Mazlan Abdul Wahid. "Necessity of biodiesel utilization as a source of renewable energy in Malaysia." Renewable and Sustainable Energy Reviews 16, no. 8 (2012): 5732-5740. https://doi.org/10.1016/i.rser.2012.05.025

[32] Pettersson, Anita, Maria Zevenhoven, Britt-Marie Steenari, and Lars-Erik Åmand. "Application of chemical fractionation methods for characterisation of biofuels, waste derived fuels and CFB co-combustion fly ashes." Fuel 87, no. 15-16 (2008): 3183-3193. https://doi.org/10.1016/i.fuel.2008.05.030

[33] McDowall, Will, Gabrial Anandarajah, Paul E. Dodds, and Julia Tomei. "Implications of sustainability constraints on UK bioenergy development: Assessing optimistic and precautionary approaches with UK MARKAL." Energy Policy 47 (2012): 424-436. https://doi.org/10.1016/i.enpol.2012.05.015

[34] Isikgor, Furkan H., and C. Remzi Becer. "Lignocellulosic biomass: a sustainable platform for the production of biobased chemicals and polymers." Polymer Chemistry 6, no. 25 (2015): 4497-4559. https://doi.org/10.1039/C5PY00263J

[35] Opia, Anthony Chukwunonso, Abdul Hamid Mohd Kameil, Zul Hilmi Che Daud, Stanley Chinedu Mamah, Mazali Izhari Izmi, and Abu Bakar Abd Rahim. "Tribological properties enhancement through organic carbon nanotubes as nanoparticle additives in boundary lubrication conditions." Jurnal Tribologi 27 (2020): 116-131.

[36] Mu, Liwen, Jian Wu, Leonidas Matsakas, Minjiao Chen, Alireza Vahidi, Mattias Grahn, Ulrika Rova, Paul Christakopoulos, Jiahua Zhu, and Yijun Shi. "Lignin from hardwood and softwood biomass as a lubricating additive to ethylene glycol." Molecules 23, no. 3 (2018): 537. https://doi.org/10.3390/molecules23030537

[37] Kamm, Birgit, Patrick R. Gruber, and Michael Kamm, eds. Biorefineries-industrial processes and products. No. 1. Weinheim, Germany: Wiley-VCH, 2006. https://doi.org/10.1002/14356007.104 101 
[38] Gupta, A. K. "Thermal characteristics of gaseous fuel flames using high temperature air." Journal of Engineering for Gas Turbines and Power 126, no. 1 (2004): 9-19. https://doi.org/10.1115/1.1610009

[39] Thomas, Nussbaumer. "Combustion and co-combustion of biomass: Fundamentals, technologies, and primary measures for emission reduction." Energy \& Fuels 17, no. 6 (2003): 1510-1521. https://doi.org/10.1021/ef030031q

[40] Zhou, Dong, Liang Zhang, Shicheng Zhang, Hongbo Fu, and Jianmin Chen. "Hydrothermal liquefaction of macroalgae Enteromorpha prolifera to bio-oil." Energy \& Fuels 24, no. 7 (2010): 4054-4061. https://doi.org/10.1021/ef100151h

[41] Taleghani, Giti, and Akbar Shabani Kia. "Technical-economical analysis of the Saveh biogas power plant." Renewable Energy 30, no. 3 (2005): 441-446. https://doi.org/10.1016/i.renene.2004.06.004

[42] Sies, Mohsin Mohd, and Mazlan Abdul Wahid. "Numerical Investigation of the Asymmetrical Vortex Combustor Running on Biogas." Journal of Advanced Research in Fluid Mechanics and Thermal Sciences 74, no. 1 (2020): 1-18. https://doi.org/10.37934/arfmts.74.1.118

[43] Uslu, Ayla, André PC Faaij, and Patrick CA Bergman. "Pre-treatment technologies, and their effect on international bioenergy supply chain logistics. Techno-economic evaluation of torrefaction, fast pyrolysis and pelletisation." Energy 33, no. 8 (2008): 1206-1223. https://doi.org/10.1016/i.energy.2008.03.007

[44] Turn, Scott Q., Charles M. Kinoshita, and Darren M. Ishimura. "Removal of inorganic constituents of biomass feedstocks by mechanical dewatering and leaching." Biomass and Bioenergy 12, no. 4 (1997): $241-252$. https://doi.org/10.1016/S0961-9534(97)00005-6

[45] Noyola, Adalberto, Juan Manuel Morgan-Sagastume, and Jorge E. Lopez-Hernandez. "Treatment of biogas produced in anaerobic reactors for domestic wastewater: odor control and energy/resource recovery." Reviews in Environmental Science and Bio/Technology 5, no. 1 (2006): 93-114. https://doi.org/10.1007/s11157-005-2754-6

[46] Balat, Mustafa, Mehmet Balat, Elif Kırtay, and Havva Balat. "Main routes for the thermo-conversion of biomass into fuels and chemicals. Part 1: Pyrolysis systems." Energy Conversion and Management 50, no. 12 (2009): $3147-3157$. https://doi.org/10.1016/i.enconman.2009.08.014

[47] Palash, S. M., M. A. Kalam, H. H. Masjuki, B. M. Masum, IM Rizwanul Fattah, and M. Mofijur. "Impacts of biodiesel combustion on NOx emissions and their reduction approaches." Renewable and Sustainable Energy Reviews 23 (2013): 473-490. https://doi.org/10.1016/i.rser.2013.03.003

[48] Reddy, V. Mahendra, Pratim Biswas, Prateek Garg, and Sudarshan Kumar. "Combustion characteristics of biodiesel fuel in high recirculation conditions." Fuel Processing Technology 118 (2014): 310-317. https://doi.org/10.1016/i.fuproc.2013.10.004

[49] Koh, May Ying, and Tinia Idaty Mohd. "Ghazi. A review of biodiesel production from Jatropha curcas L. oil." Renewable and Sustainable Energy Reviews 15, no. 5 (2011): $2240-2251$. https://doi.org/10.1016/i.rser.2011.02.013

[50] Khan, A. A., Wiebren de Jong, P. J. Jansens, and H. Spliethoff. "Biomass combustion in fluidized bed boilers: Potential problems and remedies." Fuel Processing Technology 90, no. 1 (2009): 21-50. https://doi.org/10.1016/i.fuproc.2008.07.012

[51] Prins, Mark J., Krzysztof J. Ptasinski, and Frans J. J. G. Janssen. "From coal to biomass gasification: Comparison of thermodynamic efficiency." Energy 32, no. 7 (2007): 1248-1259. https://doi.org/10.1016/i.energy.2006.07.017

[52] Koutinas, Apostolis A., Ruo-Hang Wang, and Colin Webb. "The biochemurgist-bioconversion of agricultural raw materials for chemical production." Biofuels, Bioproducts and Biorefining: Innovation for A Sustainable Economy 1, no. 1 (2007): 24-38. https://doi.org/10.1002/bbb.6

[53] Zhu, Shanglong, Artur Pozarlik, Dirk Roekaerts, Hugo Correia Rodrigues, and Theo van der Meer. "Numerical investigation towards HiTAC conditions in laboratory-scale ethanol spray combustion." Fuel 211 (2018): $375-389$. https://doi.org/10.1016/i.fuel.2017.09.002

[54] de Jong, Wiebren, Ömer Ünal, Jans Andries, Klaus RG Hein, and Hartmut Spliethoff. "Biomass and fossil fuel conversion by pressurised fluidised bed gasification using hot gas ceramic filters as gas cleaning." Biomass and Bioenergy 25, no. 1 (2003): 59-83. https://doi.org/10.1016/S0961-9534(02)00186-1

[55] Kalisz, Sylwester, Marek Pronobis, and David Baxter. "Co-firing of biomass waste-derived syngas in coal power boiler." Energy 33, no. 12 (2008): 1770-1778. https://doi.org/10.1016/j.energy.2008.08.001

[56] Chen, Lei, Sze Zheng Yong, and Ahmed F. Ghoniem. "Oxy-fuel combustion of pulverized coal: Characterization, fundamentals, stabilization and CFD modeling." Progress in Energy and Combustion Science 38, no. 2 (2012): 156214. https://doi.org/10.1016/j.pecs.2011.09.003

[57] Colorado, A. F., B. A. Herrera, and A. A. Amell. "Performance of a flameless combustion furnace using biogas and natural gas." Bioresource Technology 101, no. 7 (2010): 2443-2449. https://doi.org/10.1016/i.biortech.2009.11.003

[58] Xing, Fei, Arvind Kumar, Yue Huang, Shining Chan, Can Ruan, Sai Gu, and Xiaolei Fan. "Flameless combustion with liquid fuel: A review focusing on fundamentals and gas turbine application." Applied Energy 193 (2017): 28-51. https://doi.org/10.1016/j.apenergy.2017.02.010

[59] Hosseini, Seyed Ehsan, and Mazlan Abdul Wahid. "Development of biogas combustion in combined heat and power 
generation." Renewable and Sustainable Energy Reviews $40 \quad$ (2014): 868-875. https://doi.org/10.1016/i.rser.2014.07.204

[60] Abuelnuor, A. A. A., M. A. Wahid, Seyed Ehsan Hosseini, A. Saat, Khalid M. Saqr, Hani H. Sait, and M. Osman. "Characteristics of biomass in flameless combustion: A review." Renewable and Sustainable Energy Reviews 33 (2014): 363-370. https://doi.org/10.1016/j.rser.2014.01.079

[61] Ghenai, Chaouki, and Isam Janajreh. "Combustion of Renewable Biogas Fuels." Journal of Energy and Power Engineering 9 (2015): 831-843. https://doi.org/10.17265/1934-8975/2015.10.001

[62] Levy, Yeshayahou, Valery Sherbaum, and Patric Arfi. "Basic thermodynamics of FLOXCOM, the low-NOx gas turbines adiabatic combustor." Applied Thermal Engineering 24, no. 11-12 (2004): 1593-1605. https://doi.org/10.1016/i.applthermaleng.2003.11.022

[63] Hosseini, Seyed Ehsan, Mazlan A. Wahid, and Abuelnuor Abdeen Ali Abuelnuor. "Biogas flameless combustion: a review." In Applied Mechanics and Materials, vol. 388, pp. 273-279. Trans Tech Publications Ltd, 2013. https://doi.org/10.4028/www.scientific.net/AMM.388.273

[64] Guillou, Erwann, Ephraim Gutmark, and Michael Cornwell. "Application of Flameless Combustion for Gas Turbine Engine." In 47th AIAA Aerospace Sciences Meeting Including The New Horizons Forum and Aerospace Exposition, p. 225. 2009. https://doi.org/10.2514/6.2009-225

[65] Sharma, Saurabh, Hrishikesh Pingulkar, Arindrajit Chowdhury, and Sudarshan Kumar. "A new emission reduction approach in MILD combustion through asymmetric fuel injection." Combustion and Flame 193 (2018): 61-75. https://doi.org/10.1016/i.combustflame.2018.03.008

[66] Miller, Sharon Falcone, and Bruce G. Miller. "The occurrence of inorganic elements in various biofuels and its effect on ash chemistry and behavior and use in combustion products." Fuel Processing Technology 88, no. 11-12 (2007): 1155-1164. https://doi.org/10.1016/i.fuproc.2007.06.030

[67] Masiá, AA Tortosa, B. J. P. Buhre, R. P. Gupta, and T. F. Wall. "Characterising ash of biomass and waste." Fuel Processing Technology 88, no. 11-12 (2007): 1071-1081. https://doi.org/10.1016/i.fuproc.2007.06.011

[68] Hosseini, Seyed Ehsan, and Mazlan Abdul Wahid. "Biogas utilization: Experimental investigation on biogas flameless combustion in lab-scale furnace." Energy Conversion and Management 74 (2013): 426-432. https://doi.org/10.1016/i.enconman.2013.06.026

[69] Khalil, Ahmed E. E., and Ashwani K. Gupta. "Swirling distributed combustion for clean energy conversion in gas turbine applications." Applied Energy 88, no. $11 \quad$ (2011): $3685-3693$. https://doi.org/10.1016/i.apenergy.2011.03.048

[70] Bagheri, Ghobad, Ehsan Hamidi, Mazlan A. Wahid, Aminuddin Saat, and Mohsin M. Sies. "Effects of CO2 Dilution on the Premixed Combustion of CH4 in Microcombustor." In Applied Mechanics and Materials, vol. 388, pp. 251256. Trans Tech Publications Ltd, 2013. https://doi.org/10.4028/www.scientific.net/AMM.388.251

[71] Wang, Y. D., D. Mcllveen-Wright, Y. Huang, N. Hewitt, P. Eames, S. Rezvani, J. McMullan, and A. P. Roskilly. "The application of FLOX/COSTAIR technologies to reduce NOx emissions from coal/biomass fired power plant: A technical assessment based on computational simulation." Fuel 86, no. 14 (2007): 2101-2108. https://doi.org/10.1016/i.fuel.2007.01.013

[72] Hosseini, Seyed Ehsan, Ghobad Bagheri, and Mazlan Abdul Wahid. "Numerical investigation of biogas flameless combustion." Energy Conversion and Management $81 \quad$ (2014): $41-50$. https://doi.org/10.1016/i.enconman.2014.02.006

[73] Li, Jun, Hongyu Huang, Yugo Osaka, Yu Bai, Noriyuki Kobayashi, and Yong Chen. "Combustion and heat release characteristics of biogas under hydrogen-and oxygen-enriched condition." Energies 10, no. 8 (2017): 1200. https://doi.org/10.3390/en10081200 